\title{
THE STRANGE CAREER OF "STATE ACTION" UNDER THE FIFTEENTH AMENDMENT
}

IN passing the Voting Rights Act of $1965,{ }^{1}$ Congress has taken the position that its enforcement power under the fifteenth amendment ${ }^{2}$ extends not only to "state action," but to private conduct as well. The criminal provisions of the Act punish interference with the right to vote free of racial discrimination, whether that interference stems from action "under color of law or otherwise."3 Congress' judgment was based on recent decisions under the Reconstruction amendments, especially under the fifteenth, which have eroded the state action requirement. ${ }^{4}$ Nevertheless, doubts persist ${ }^{5}$ that the Court will disavow explicitly a doctrine continually reaffirmed as "firmly embedded in

1. ........ Stat. ....... (1965). (At the time at which this Note went to press, S.1564 and H.R. 6400, 89th Cong., 1st Sess. (1965)).

2. Power to "enforce" the fifteenth amendment is explicitly conferred upon Congress by its second section. The amendment reads in its entirety:

SECTION 1. The right of citizens of the United States to vote shall not be denied or abridged by the United States or by any State on account of race, color, or previous condition of servitude -

SEctron 2. The Congress shall have power to enforce this article by appropriate legislation.

3. Both the Senate and House bills departed from the organization and wording of the original version sent to Congress by the President, but each retains its proscription of both official and private interference:

H.R. 6400, 89th Cong., 1st Sess. (1965): Sec. 11. No person, whether acting under color of law or otherwise, shall intimidate, threaten, or coerce, or attempt to intimidate, threaten, or coerce any person for voting or attempted voting, or for urging or aiding such voting or attempted voting.

S. 1564, 89th Cong., 1st Sess. (1965) : Sec. 11(b). No person, whether acting under color of law or otherwise, shall intimidate, threaten, or coerce, or attempt to int timidate, threaten, or coerce any person from voting or attempted voting . . .

4. See, for analysis of the recent case-law, e.g., Van Alstyne and Karst, State Action, 14 Stan. L. Rev. 3, 23-26, $42-43$ (1961) ; Williams, The Trwilight of State Action, 41 T'ex. L. Rev. 347 (1963); Pollak, Racial Discrimination and Judicial Integrity: A Reply to Professor Wechsler, 108 U. PA. L. Rev. 1, $19-23$ (1959) ; Cf. Lewis, The Meaning of Statc Action, 60 Colur. L. Rev. 1083 (1960) ; Abernathy, Expansion of the State Action Concept under the Fourteenth Amendment, 43 CoRneli L.Q. 375 (1958); Henkin, Shelley v. Kramer: Notes for a Revised Opinion, 110 U. PA. L. REv. 473 (1962); St. Antoinc, Color Blindness but not Myopia: A New Look at State Action, Equal Protection, and "Private" Discrimination, 59 MICH. L. REv. 993 (1961). The Court's preferential treatment of the fifteenth amendment has not met with unanimous approval. See Wechsler, Towvard Nculral Principles of Constitutional Law, 73 HARv. L. REv. 1, 28-29 (1959).

5. In the House, the criminal provisions of the Act were modified while the bill was under review by Subcommittee No. 5 of the Judiciary Committee so as to apply to state action alone. The provisions were restored to their original scope by the full committce. When the bill was sent to the floor of the House, the Republican minority of the Judiciary Committee remained persuaded that the criminal provisions were not constitutional. Sce H.R. REP. No. 439, 89th Cong., 1st Sess. 52 (1965). 
our constitutional law." These doubts rest on the assumption that state action has always been a requirement under both Reconstruction amendments. ${ }^{7}$ In fact, however, this assumption is not accurate, for the earliest cases construe congressional enforcement power under the fifteenth amendment to reach private individuals, even though the identical language of the fourteenth amendment was construed to reach state action alone. ${ }^{8}$

The doctrinal basis for those early decisions was the rule enunciated in Prigg v. Pennsylvania. ${ }^{9}$ In that pre-Civil War case, the Supreme Court sustained the constitutionality of the Fugitive Slave Act of 1793 against the argument that the act was void because it did not "fall within the scope of any of the enumerated powers of legislation confided to that body."10 Justice Story wrote for the Court:

If, indeed, the constitution guarantees the right, and if it requires the delivery upon the claim of the owner.... the natural inference certainly is, that the national government is clothed with the appropriate authority and functions to enforce it. The fundamental principle, applicable to all cases of this sort, would seem to be, that where the end is required, the means are given....11

6. Burton v. Wilmington Parking Authority, 365 U.S. 715, 721-22 (1961); Shelles" v Kramer, 334 U.S. 1, 13 (1948).

7. Ibid. See also United States v. Classic, 313 U.S. 299, 315 (1941) and Gressman, The Unhappy History of Civil Rights Legislation, $40 \mathrm{MIrcH}$. L. REv. 1323, 1339-40 (1952). Contemporary analyses of the case-law of the late and post-Reconstruction cra appear to be dominated by the assumption that the leading decisions can be understood wholly as products of judicial antagonism to the aims of the Reconstruction amendments. See, e.g., Gressman, supra, at 1336-40; HaRRis, The QUEST For EQUALrTY 56, 81-89 (1960); Frank and Munro, The Original Understanding of Equal Protection of the Lon's, 50 Colums. L. Rev. 131, 167 (1950). A more sophisticated view sees in these cases an attempt to rationalize the law with the retreat of the northern populace and the federal political branches from their ephemeral commitment to those aims. Woodward, Tre Burder of SOUTHERN FIISTORY 84 (1960).

On the other hand, much of contemporary thinking reflects the belief that the very language of the amendments dictates the state action rule announced in those decisions. Mlost of the modern attempts to derive support, for reaching private conduct do not flatly reject the rule. Instead, modern approaches extend the concept of state responsibility to encompass certain instances of private conduct. See the works cited in note 4, supra, and text following note 49 , infra. Both of these assumptions have obscured the fact that the policy and doctrinal conceptions which shaped the law of the period gave ample room for federal prevention of racial violence and intimidation in the South.

8. A recent contributor to this journal argues persuasively that the courts of the 1870 's and 1880's actually adopted what can be termed the "breakdown" theory of state action regarding the fourteenth amendment. Under this theory, Congress is empowered to reach private conduct in the event of failure by the states to protect the rights secured by that amendment. Frantz, Congressional Power to Enforce the Fourleculh Amendment Against Private Acts, 73 Yale L.J. 1353, 1359-60 (1964).

9. 41 U.S. (17 Pet.) 539 (1842).

10. Id. at 617-18.

11. Id. at 614-15. 
The implied power doctrine of Prigg v. Pennsylvania was invoked in defense of the Radical enforcement legislation ${ }^{12}$ which, like the 1965 Act, reached private action. The first circuit court decisions reviewing the legislation accepted the argument that Congress had implied power to protect the right guaranteed by the fifteenth amendment against private action. ${ }^{13}$ However, this theory did not withstand an authoritative test until 1874, when Supreme Court Justice Bradley sat as Circuit Justice in United States v. Cruikshank.14 This case concerned the application of the legislation to the slaying of a group of Negroes assembled for a political meeting. ${ }^{15}$ After quoting at length from Justice Story's opinion in Prigg, Justice Bradley concluded that Prigg "firmly established ... that Congress has power to enforce, by appropriate legislation every right given or guaranteed by the Constitution." Congress' power, however, was not unreviewable: "The method of enforcement, or the legislation appropriate to that end, will depend upon the character of the right con-

12. Mathews, Legislative and Judicial History of the Fifteente Amendment 86, 92-93 (1909); Cf. Flack, The Adoption of the Fourteenth Adendment 210-77 (1908); Ten Broek, The Antislavery Origins of the Fourteentu Amendment 98 (1951); Frantz, supra note 10 at 1357-58. Soon after the ratification of the fiftenth amendment, Congress enacted three statutes aimed at suppressing southern resistance to the implementation of the fifteenth and fourteenth Amendments. Popularly known as the Enforcement Act, the Force Act, and the Ku Klux Act, the statutes were: Act of May 31, 1870, 16 Stat. 140; Act of Feb. 28, 1871, 16 Stat. 933; Act of April 20, 1871, 17 Stat. 13. The statutes were codified in Sections 5506-5532 of the Revised Statutes (1875). Although many of the sections have since been repealed and all have been modificd in some measure, this Reconstruction legislation still forms the basis of federal statutory civil rights law. See, e.g., 18 U.S.C. $\$ \S 241,242 ; 42$ U.S.C. $\$ \$ 1971-89 ; 28$ U.S.C. $\$ \S 1343$, 1443 (1964). For a review of the evolution of the legislation until the mid-twentieth century, see generally Gressman, supra note 7.

13. United States v. Given, 25 Fed. Cas. 1324, 1325-26 (No. 15, 210) (C.C.D. Del. 1873); United States v. Hall, 26 Fed. Cas. 79, $81-82$ (No. 15, 282) (C.C.D. Ala. 1871); United States v. Crosby, 25 Fed. Cas. 701 (No. 14, 893) (C.C.D. S.C. 1871).

14. 25 Fed. Cas. 707 (No. 14, 897) (C.C.D. Ia. 1874). Justice Bradley is said to have been persuaded to appear as Circuit Justice by counsel for the defendants. Cumminds \& McFarland, Federal Justice 243 (1937).

15. The defendants had allegedly set afire a building in which a group of Negroes were holding their meeting, and then shot the Negroes down as they tried to escape the fire. Cuamings \& MCFARLAND, op. cit. supra note 14 at 241-42. This incident was a paradigm of the methods used to drive the Negro and the Republican Party from southern politics during the 1870's. Swinney, Enforcing the Fifteenth Amendment, 1870-77, $28 \mathrm{~J}$. So. Hist. 202 (1962); Wharton, The Negro in Mississtrpi 167-99 (1947); Cummintes \& MCFARLAND at 231-49. In South Carolina in 1871, the Department of Justice was able to suppress the $\mathrm{Ku}$ Klux Klan with the aid of mass arrests and prosecutions, the extensive use of federal troops, periodic suspension of habeas corpus, and with the support of local mercantile and planting interests. Cummings \& MCFARLAND, supra at 238-39; Randal. \& Donald, The Ctvil War and Reconstruction 684 (1961). But the determination of the mass of southern whites to disfranchise the Negro by all available means proved more enduring than the commitment of the northern white populace and of wealthy solthern whites to protect the freedman. Swinney, supra at 218; Wriarton, op. cil. supra at 193.94; Woodward, Origins of the NEW SOUTH 321 (1950). 
ferred."16 Bradley did not find the prohibitory language of the Reconstruction amendments dispositive of the "character of the rights conferred" by either amendment. With respect to the fifteenth amendment, Bradley reasoned:

Although negative in form, and therefore, at first view, apparently to be governed by the rule that congress has no duty to perform until the state has violated its provisions, nevertheless in substance it confers a positive right which did not exist before .... [T] he history of the events out of which the amendment grew shows that it was principally intended to confer upon colored citizens the right of suffrage .... [I]t does have the affirmative effect of conferring upon them an equal right to vote with that enjoyed by white citizens.

Justice Bradley emphasized, however, that the amendment did not create a federal right to vote, but only a federal right to vote on the same terms as white people. Therefore Congress could not "regulate elections or the right of voting," except to correct racial discrimination. ${ }^{18}$ But Congress could protect equal access to the franchise even against private interference.

The real difficulty in the present case is to determine whether the amendment has given Congress any power to legislate except to furnish redress in cases where the states violate the amendment. Considering, as before intimated, that the amendment, notwithstanding its negative form, substantially guarantees the equal right to vote to citizens of every race and color, I am inclined to the opinion that Congress has the power to secure that right not only as against the unfriendly operation of state laws, but against outrage, violence, and combinations on the part of individuals, irrespective of state laws. ${ }^{10}$

Notwithstanding this broad interpretation, Bradley dismissed the indictment in Cruikshank on the ground that the government had failed to allege racial motivation..$^{20}$ The dismissal should not be taken as a retreat from the theory of federal power expressed in the opinion:

According to my view the law on the subject may be generalized in the following proposition : the war of race, whether it assumes the dimensions of civil strife or domestic violence, whether carried on in a guerilla or a predatory form, or by private combinations, or even by private outrage or intimidation, is subject to the jurisdiction of the government of the United States; and when any atrocity ... may be assigned to this cause it may be punished by the laws and in the courts of the United States; but any outrages, atrocities, or conspiracies, whether against the colored race or the white race, which do not flow from this cause, but spring from ... ordinary felonious or criminal intent ... are ... within the sole jurisdiction of the states, unless, indeed, the state, by its laws, denies to any particular race equality of rights....21

16. 25 Fed. Cas. at 710.

17. Id. at 712 .

18. Ibid.

19. Id. at 713 .

20. Id. at 715. The indictment, Bradley held, therefore went beyond what was appropriate for the protection of the limited right conferred by the fifteenth amendment.

21. Like Justice Miller in the previously decided Slaughter-House Cases, 83 U.S. (16 Wall.) 36 (1873), Justice Bradley appears in Cruikshank to have approzched 
Although the prohibitory words of the fourteenth and fifteenth amendments were identical,22 Justice Bradley did not construe the fourteenth as liberally as he had the fifteenth. The rights covered by the fourteenth amendment, and hence the appropriate means of protecting them, differed.

With regard to those acknowledged rights and privileges of the citizen, which form a part of his political inheritance derived from the mother country, and which were challenged and vindicated by centuries of stubborn resistance to arbitrary power, they belong to him as his birthright, and it is the duty of the particular state of which he is a citizen to protect and to enforce them .... When any of these rights and privileges are secured in the constitution of the United States only by a declaration that the state or the United States shall not violate or abridge them, it is at once understood that they are not created or conferred by the constitution, but that the constitution only guarantees that they shall not be impaired by the states .... The affirmative enforcement of the rights and privileges themselves, unless something more is shown, does not devolve upon the United States but belongs to the state government as a part of its residuary sovereignty. ${ }^{23}$

Bradley construed the fourteenth amendment restrictively becatuse he feared the creation of a federal "municipal" power. If that amendment could be enforced against private individuals, then the due process clause cottd become a basis for federalizing "ordinary" crimes like "murder, false imprisonment, [and] robbery,"24 and the privileges and immunities clause could become the basis for federalizing the protection of "fundamental rights," stich as the right of assembly. "This would be to clothe congress with the power to pass laws for the general preservation of social order."25 Since the langtage of the amendment was ambiguous, the Court should construe the amendment to prohibit such a significant shift of power from the states to the federal government. ${ }^{28}$

the task of construing the Civil War Amendments with a view toward sanctioning federal measures to cope with the "emergency" of emancipation without "destroying the main features of the general system." 83 U.S. at 71-72, 82. Bradley's distinction between the scope of congressional enforcement power under the two amendments neatly resolved the conflict between these two policy aims. By limiting the fourteenth amendment to state action, he quashed a perceived threat to the general primacy of local responsibility for the preservation of domestic order. See notes 23-26 infra and accompanying text. But the fifteenth amendment alone gave the federal government ample power to move against racist vigilantism in the South, since virtually all such terrorist activities were, in fact, at least partly aimed at driving the Negro out of politics. See note 15 supra.

22. Section 1 of the fourteenth amendment reads in part:

No State shall make or enforce any law which shall abridge the privileges or immunities of citizens of the United States; nor shall any State deprive any person of life, liberty, or property, without due process of law; nor deny to any person within its jurisdiction the equal protection of the laws.

23. 25 Fed. Cas. at 710 (emphasis added).

24. Ibid.

25. Id. at $710,714$.

26. Id. at 710. Frantz notes correctly that Justice Bradley did not prohibit altogether congressional proscription of private conduct under the fourteenth amendment, but applicd the "breakdown" theory of state action to that amendment. See note 8 sthpra. 
The decisions of the Supreme Court in Cruikshank and the companion case of United States $v$. Reese ${ }^{27}$ adopted both the results and the reasoning of Justice Bradley's decision. Chief Justice Waite held that the fourteenth amendment did not create any new rights, but merely guaranteed against state infringement rights which had existed prior to and independent of the Constitution. Therefore, Congress could proscribe only state action under that amendment. ${ }^{28}$ However, the Court held that the fifteenth amendment had

invested citizens of the United States with a new constitutional right ... exemption from discrimination in the exercise of the elective franchise on account of race, color or previous condition of servitude. From this it appears that the right of suffrage is not a necessary attribute of national citizenship; but that exemption from discrimination in the exercise of that right on account of race, \&c., is . . . . The first has not been granted or secured by the Constitution of the United States; but the last has been.?

By inference, any right that constituted an "attribute of national citizenship" could be protected from private interference. Nevertheless, the Court found the counts under the fifteenth amendment deficient on the same ground as had Justice Bradley - the Government's failure to allege racial motivation by the defendants. ${ }^{30}$

In $E_{x}$ Parte Yarbrough ${ }^{31}$ racial motivation was alleged, ${ }^{32}$ and the Supreme Court upheld the application of the fifteenth amendment to private interference. Repeating Justice Bradley's argument in Cruilishank on circuit, the Court held that the amendment "conferred" upon southern Negroes a new constitutional right.

While it is quite true, as was said by this court in United States $v$. Reese, that this article gives no affirmative right to the colored man to vote, and is designed primarily to prevent discrimination against him whenever the right to vote may be granted to others, it is easy to see that under some circumstances, it may operate as the immediate source of a right to vote. In all cases where the former slave-holding States had not removed from their Constitutions the words "white man" as a qualification for voting,

27. 92 U.S. $542 ; 92$ U.S. 214 (1876).

29. Id. at 555-56. See United States v. Reese, 92 U.S. 214, at 217-18 (1876).

30. Id. at 556. The Court stated :

Inasmuch ... as it does not appear in these counts that the intent of the defendants was to prevent these parties from exercising their right to vote on account of their race, etc., it does not appear that it was their intent to interfere with any right granted or secured by the constitution or laws of the United States. We may suspect that race was the cause of the hostility; but it is not so averred. This is material to a description of the substance of the offense, and it cannot be supplied by implication.

31. 110 U.S. 651 (1884).

32. Id. at 655-56. The petitioners had been convicted of violating the provisions of two sections of the enforcement legislation, Sections 5503 and 5520 of the Revised Statutes. Section 5520, repealed in 1894 (28 Stat. 36), outlawed interference with the right to vote in federal elections alone. Section 5508, now 18 U.S.C. $\$ 241$, outlawed conspiracies to interfere with the exercise and enjoyment of rights secured by the Constitution or laws of the United States. 
this provision did, in effect, confer on him the right to vote. . . .

In such cases this fifteenth article of amendment does, proprio vigorc, substantially confer on the negro the right to vote, and Congress has the power to protect and enforce that right.

Justice Miller then underlined the distinction drawn between the two Recon* struction amendments in Cruikshank:

The reference to cases in this court in which the power of Congress under the first section of the Fourteenth Amendment has been held to relate alone to acts done under State authority, can afford petitioners no aid in the present case. For, while it may be true that acts which are mere invasions of private rights, which acts have no sanction in the statutes of a State, or which are not committed by anyone exercising its atthority, are not within the scope of that amendment, it is quite a different matter when Congress undertakes to protect the citizen in the exercise of rights conferred by the Constitution of the United States essential to the healthy organization of the government itself. ${ }^{33}$

Presently, Yarbrough is considered to stand only for the rule derived in the first part of the opinion - that the right of all citizens to vote in federal elections can be protected from private interference. ${ }^{34}$ The second part of the opinion, which established that Congress could protect fifteenth amendment rights from private interference, has been ignored. ${ }^{35}$ But the case must stand for this proposition, too, or the second branch of the argument would be superfluous. Rights under the fifteenth amendment and the right to vote in federal elections were both held to be "conferred" by the Constitution, "0 indicating that the Court intended each right to serve equally as justification for the holding..$^{\text {t7 }}$

Ex Parte Yarbrough completes a picture of the scope which the Court wished to give the Reconstruction amendments. ${ }^{38}$ By 1884, however, Congress and the Department of Justice were showing little disposition to use the power defined by the Court. ${ }^{30}$ The mood of the country turned from apathy to sympathy for the position of the southern white. ${ }^{40}$ Reconstruction was viewed as a futile experiment, partially sinister, partially naive. ${ }^{\mathbf{1 1}}$ Judicial decisions at the

33. 110 U.S. at 665-66. The fourteenth amendment cases referred to by the Court are United States v. Harris, 106 U.S. 629 (1883) and The Cizil Rights Cases, 109 U.S. 3 (1883). These cases are considered, along with Cruikshank, to be the historical basis of the state action doctrine. Burton v. Wilmington Parking Authority, 365 U.S. 715, 721-22 (1961) ; Collins v. Hardyman, 341 U.S. 651, 658 (1951).

34. Id. at 660-64.

35. See, e.g., United States v. Classic, 313 U.S. 299, 315 (1941); United States v. Williams, 341 U.S. 70, 77 (1951).

36. 110 U.S. at $663-64,665-66$.

37. Cf. notes 16-19, 23, 29 supra and accompanying text. The Court reporter summarized the second branch of the Court's argument as "qualifying" and "explaining" United States v. Reese, 110 U.S. at 652.

38. See note 21 supra.

39. See Cummings \& McFardand, op. cit. sispra note 18 , at 246-49; Whinton, op. cit. supra note 19, at 193-94.

40. Woodward, Origins of the New South at 324-25; Woodward, The Strange CAREER OF JiM CROW 52-53 (1957).

41. WOODWARD, ORIGINS 325. 
turn of the century reflected the sentiments of the nation. Plessy v. Fergusons held state-enforced racial segregation consistent with the equal protection clause of the fourteenth amendment.42 And Williams $v$. Mississippi held that Mississippi's plan to legalize white supremacy as the basis of its political institutions did not violate the fifteenth amendment. ${ }^{33}$

Finally, in James v. Bowman, the Supreme Court held that state action was required by the fifteenth as well as the fourteenth amendment. ${ }^{\text {.4 }}$ The Boruman Court failed to mention Yarbrough, ${ }^{45}$ referred only to that portion of Cruilkshank which construed the fourteenth amendment, ${ }^{40}$ and used Reese as its principal source of authority ${ }^{47}$ - for a proposition palpably in conflict with the rationale of Reese itself. 48

Since James v. Bowman it has been assumed that the state action requirement is dictated by the terms of both the fourteenth and fifteenth amendments. ${ }^{49}$ However, the courts have experienced difficulty in reconciling the purpose of the fifteenth amendment with this construction of its terms. In order to avoid legitimating attempts to transfer to private hands the means of perpetuating Negro disfranchisement, the Supreme Court's definition of state action has been continuously extended. Now, the Court may be receptive to the argument that James $v$. Bormman should be explicitly overruled, for that case has been so eroded that it is no longer a meaningful limitation on federal power. Indeed, in Terry v. Adams, ${ }^{50}$ the most recent major decision under the fifteenth amendment, Mr. Justice Black appears to have discarded the state action requirement altogether and returned to the more liberal doctrine of the nineteenth century.

In the earliest of the twentieth century cases the Court evolved a simple approach to state action analysis - the "state participation" theory. Under this theory the fifteenth amendment can be applied to private conduct if the state

42. 163 U.S. 537 (1896).

43. 170 U.S. 213 (1898). Other states in the South followed Afississippi's lead in institutionalizing disfranchisement during this period. See Woodward, OnIaws 327-49. Williams v. Mississippi appears to have been finally assigned to oblivion in the companion cases United States v. Mississippi, 380 U.S. 128 and Louisiana v. United States, 380 U.S. 145 (1965).

44. 190 U.S. 127 (1903).

45. The Court's failure to refer to Yarbrongh or to the distinction between the two Reconstruction amendments originated in Reese and Cruikshank and reaffirmed in that case is especially striking, as the Solicitor General, representing the appellants, grounded his argument on those cases and on that distinction. 190 U.S. at 129-30.

46. 190 U.S. at 136-37.

47. Id. at 138-39.

48. United States v. Reese, 92 U.S. 214, 217-18. The doctrinal step bachward represented by James $v$. Bozemnan was noted by one commentator who observed that the fifteenth amendment, in all but "the technical sense," was "in process of repeal," adding that "the real reason behind the attitude of both Congress and the courts" was "the apathetic tone of public opinion..." Matrews, op. cit. supra note 12 at 126 (1909).

49. See notes 7 and 35 sipra.

50. 345 U.S. 461 (1953). See notes 71-78 infra. 
played some role in the discriminatory act. Participation could be shown if official coercion limited the freedom of the private association to discriminate or not discriminate. ${ }^{51}$ But if the membership of the association voluntarily excluded Negroes, then the amendment did not apply. ${ }^{.2}$

In Smith $v$. Allwright, ${ }^{63}$ the Court rejected this rule and held that the fifteenth amendment prohibited the Democrats from choosing to exclude Negroes from their primary. Instead of determining whether the state coerced the decision to discriminate, the Court examined the statutes regulating the party's activities and concluded that

this statutory system for the selection of party nominees for inclusion on the general election ballot makes the party which is required to follow these legislative directions an agency of the state in so far as it determines the participants in a primary election. The party takes its character as a state agency from the duties imposed upon it by state statutes . . . .

By this reasoning the Democrats became subject to the fifteenth amendment merely because their affairs were regulated, even though the regulations were unrelated to membership policy. Since virtually all private associations are governed in some measure by state law, the expanded state participation theory employed by the Court in Smith $v$. Allworight, if applied evenhandedly, would bind all associations with similar constitutional restraints. ${ }^{65}$

If this theory appears to prove too much, a second concept of state action - the "affirmative duty" theory - completely erases the line between federal jurisdiction and state (or private) prerogative. This theory imposes upon the state a duty to prevent private interference with Negro suffrage. Under this second theory, the relevant "act" which violated the fifteenth amendment in Smith v. Allwright was not the exclusion of Negroes by the Democratic Party, but the failure of the state of Texas to prevent such exclusion.

The United States is a constitutional democracy. Its organic law grants to all citizens a right to participate in the choice of elected officials without restriction by any State because of race. This grant to the people of the opportunity for choice is not to be nullified by a State through casting its electoral process in a form which permits a private organization to

51. In Nixon v. Herndon, 273 U.S. 536 (1927) the question was whether or not a Texas statute which explicitly barred Negroes from participating in the Democratic primary violated the fourteenth and fifteenth amendments. The Court found it unnecessary to consider the fifteenth amendment, declaring the statute an obvious violation of the fourteenth. Texas then replaced the invalid statute with provisions vesting the power to prescribe qualifications for participation in the primary in the Executive Committee of the Democratic Party. The Court held, in Nixon v. Condon, 286 U.S. 73 (1932), that the Committee represented the state, not the membership of the Party, and that therefore both of the amendments applied.

52. Grovey v. Townsend, 295 U.S. 45 (1935).

53. 321 U.S. 649 (1944).

54. 321 U.S. at $663-64$.

55. Logically, the theory must also mean that such associations are to be considered "state agencies," not just for purposes of the fifteenth amendment, but for all purposes. 
practice racial discrimination in the election. Constitutional rights would be of little value if they could be thus indirectly denied. ${ }^{50}$

The affirmative duty theory might mean that a state has a duty to make a good faith effort to prevent private interference with the right to vote. Absent a willful failure to discharge that duty, and absent a finding that the failure facilitated the private conduct, federal power could not be invoked. But, from the Court's application of theory in Smith 2 . Allwright, it appears unnecessary to show any causal relation between identifiable state behavior and the proscribed private act. Consequently all that is needed to violate the amendment is the occurrence of the private act itself. Under this theory, "state action" becomes a purely formal prerequisite to the exercise of federal power.

The state action requirement was subjected to more severe strain in Terry v. Adams. ${ }^{57}$ In that case, the defendant-association was not a state regulated political party. Although the county-wide organization, known as the Jaybird Association, nearly monopolized access to Democratic nomination for local offices, ${ }^{58}$ there were no formal regulatory links between either the Democratic Party or the state and the defendant. ${ }^{59}$ The state participation theory simply could not apply. ${ }^{\circ 0}$ In addition, the Jaybirds could not accurately be labeled an auxiliary of the Democrats. Although the Association held elections preceding the Democratic primary and was organized by precincts, its nominees were not always victorious in the subsequent Democratic primary. ${ }^{01}$

The difficulties presented by this case produced an 8-1 majority for the proposition that the fifteenth amendment required the Jaybirds to admit Negroes to their membership, but little agreement about why this was so. Three opinions were handed down by the majority, none of which represented the opinion of the Court. The opinion of Mr. Justice Clark, in which three additional members of the Court joined, rested primarily on the ground that

56. Id. at 664. The Court in this passage concedes that the state has not actually engaged in any positive act to "cast" the electoral process in a form which keeps Negroes from exercising political power. Nevertheless, the Court holds that the state has "indirectly" denied petitioner his right to vote free from racial discrimination by mercly "permitting" the Democratic Party to discriminate. That is to say, the state breached its duty to prevent such discrimination.

57. 345 U.S. 461 (1953).

58. Id. at $463-65$.

59. Ibid.

60. Id. at 493 (Minton, J., dissenting).

61. Ibid. Terry v. Adams was also a different and more difficult case than two Fourth Circuit decisions cited by Mrr. Justice Black in his opinion, Rice v. Elmore, 165 F.2d 387 (4th Cir. 1947) and Baskin v. Brown, 174 F.2d 391 (4th Cir. 1949). In these cases, the court invalidated South Carolina's attempt to divest itself of its legal ties with the Democratic Party in order to avoid the decision in Smith $v$ Allauright. In this situation, the state government engaged in specific conduct designed to effectuate discrimination. But in Terry, the Jaybird Association had been formed quite independently of state participation long before the decision in Sinith v. Allwriglt. 345 U.S. at 463. The Fourth Circuit's rationale, however, reached beyond the needs of the specific facts before it, and AIr. Justice Black was justified in relying on their analysis in this respect. 
the case was indistinguishable from Smith $v$. Allwright, even though the private association in Terry was not regulated by the state as it was in Allwright. ${ }^{62}$ By ignoring the factual differences between Allwright and Terry, Mr. Justice Clark avoided dealing with the very problems which made the latter a hard case. Both Justice Minton, dissenting, ${ }^{03}$ and Justice Frankfurter, concurring, ${ }^{64}$ criticized his treatment of the facts.

The obvious weakness of the Allzuright analogy necessitated a new approach to state action - the "state function" theory ${ }^{05}$ This theory considers as covered by the Reconstruction amendments all activities normally the subject of state responsibility, whether or not the particular activity in question is formally in public or private hands. ${ }^{80}$ Unlike the state participation theory, the state function theory applies to the facts in Terry. This interpretation of the case would cover any organization which conducts elections which affect governmental elections. However, this reading of the case is not without its difficulties. It might prevent any private association which has considerable political power from restricting its membership on an arbitrary basis. ${ }^{07}$ Furthermore, there is little language in any of the opinions to indicate that the majority were significantly influenced by this mode of analysis. ${ }^{08}$

More than the state function theory, the Court emphasized theories which in effect dispose of the state action requirement completely. Both the Clark and Black opinions invoked the affirmative duty theory of Swith v. Allwright. ${ }^{9}$ As in that case, state action appears to have been understood as a purely formal requirement. ${ }^{70}$

The final two thirds of Mr. Justice Black's argument disregards the state action requirement altogether. ${ }^{71}$ The significance of this section of his opinion, like the significance of the nineteenth century cases on which it relies, has been

62. Id. at 482-84.

63. Id. at 485-89.

64. Id. at 475 .

65. Id. at $468-69,484$.

66. The leading case applying the state function theory of state action is Marsh v. Alabama, 326 U.S. 501 (1946), which held a company town subject to the fourteenth amendment.

67. Professor Wechsler criticizes the decision on the ground that it implies such a wide-ranging ban on discrimination by private associations. Wechsler, Toweard Nculral Principles of Constitutional Law, 73 Harv. L. Rev. 1, 29 (1959). Dean Pollak defends the Court's treatment of the case on the ground that, if the opinion is understood to rest on the fifteenth amendment alone, politically powerful private institutions will be barred from excluding Negroes only insofar as such exclusion prevents their effective participation in the electoral process. Pollak, Racial Discrimination and Iudicial Integrity: A Reply to Prow fessor Wechsler, 108 U. PA. L. Rev. 1, 22-23 (1959).

68. See note 65 supra. Cf. Pollak, supra at 23.

69. 345 U.S. at $466,484$.

70. See text following note 56 supra.

71. Justice Minton in his dissent interpreted the opinion of Mr. Justice Black as assuming that state action was not a necessary requirement under the amendment. 345 U.S. at 485 . 
overlooked. ${ }^{72}$ His extensive quotations from United States $v$. Recse, ${ }^{73}$ United States v. Cruikshank, ${ }^{74}$ and Ex Parte Yarbrough ${ }^{75}$ indicate that he cited them for the proposition that federal power under the fifteenth amendment extends to private as well as state action. This interpretation is strengthened by his citation of Justice Bradley's decision in Cruikshank, which fully articulated the doctrine that rights "created" or "conferred" by the Constitution may be protected from private interference. ${ }^{70}$ Unless Black understood these cases to sanction the application of federal power to private conduct, their inclusion in his argument serves no purpose. Finally, note should be taken of the terms in which Mr. Justice Black concludes his argument:

The effect of the whole procedure, Jaybird primary plus Democratic primary plus general election, is to do precisely that which the Fifteenth Amendment forbids - strip Negroes of every vestige of influence in selecting the officials who control the local county matters that intimately touch the daily lives of citizens. ${ }^{77}$

This passage echoes the approach taken by the earliest circuit court decisions - that the fifteenth amendment should be construed to prohibit all conduct which perpetuates white monopolization of the electoral process. ${ }^{78}$

Terry $v$. Adams, then, read together with the nineteenth century cases, provides precedent for congressional proscription of private conduct under the fifteenth amendment - as in the criminal provisions of the Voting Rights Act. $^{79}$ The amendment ought to be so construed. Indeed, it is unlikely that the

72. In one leading casebook on constitutional law, this portion of the opinion is entirely omitted. 2 Freud, Sutherland, Howe, Brown, Constrtutronal Law 947 (1961).

73. 345 U.S. at $467-68$.

74. Id. at 467.

75. Id. at 468 .

76. Ibid.

77. Id. at 469-70. Emphasis added.

78. United States v. Crosby, 25 Fed. Cas. 701 (No. 14, 893) (C.C.D.S.C. 1871); United States v. Given, 25 Fed. Cas. 1324 (No. 15, 210) (C.C.D. Del. 1873). In Rice v. Elmore, 165 F.2d 387 (4th Cir. 1947), the reasoning of which appears to have been adopted by Mr. Justice Black in Terry v. Adams (345 U.S. at 465), the Court employed analysis of a similar tenor:

The Fourteenth and Fifteenth Amendments were written into the Constitution to insure the Negro, who had recently been liberated from slavery, the equal protection of the laws and the right to full participation in the process of government. These amendments have had the effect of creating a federal basis of citizenship and of protecting the rights of individuals and minorities from many abuses of governmental power which were not contemplated at the time. Their primary purpose must not be lost sight of, however, and no election machinery can be upheld if its purpose and effect is to deny the Negro, on account of his race or color, any effective voice in the government of his country.

165 F.2d at 392.

79. See notes 2 and 3 supra, and accompanying text. In proseribing discrimination by the Jaybird Association, the Court was merely analyzing the extent of the power conferred on the federal judiciary by section 1 of the amendment to reach private conduct. For this reason, Terry is especially strong support for the proposition that it is "appro- 
state action requirement would have replaced this construction, had it not been for public disinterest in protecting the southern Negro. ${ }^{80}$ The tradition of local responsibility for the preservation of domestic order should not bar reinstatement of the original rule. As the nineteenth century Court recognized, fifteenth amendment jurisdiction over individual conduct will not disturb the genernl allocation of federal and state law enforcement functions. ${ }^{81}$ More important,

priate" under section 2 for Congress to reach private conduct in order to enforce the guarantee of section 1 . Of particular importance in this regard is Mr. Justice Black's obiter reference to the nature of the power conferred on Congress by section 2;

Not content to rest congressional power to protect this new constitutional right on the necessary and proper clause of the Constitution, the Fifteenth Amendment's framers added $\S 2 . .$. And Mr. Justice Miller speaking for this Court declared that the Amendment's granted right to be free from racial discrimination "... should be kept free and pure by congressional enactments whenever that is necessary." 345 U.S. at 467-68 (quoting Ex Parte Yarbrough, 110 U.S. 651, 655 (1884)).

Mr. Justice Black here appears to construe section 2 of the amendment as supplementary to, rather than in derogation of, the implied power to enforce the amendment found in the necessary and proper clause. The necessary and proper power is not subject to judicial review unless its exercise contravenes a specific constitutional prohibition. Mr. Justice Black must mean, therefore, that section 2 would authorize Congress to proscribe private interference with the operation of the amendment. This impression is reinforced by his citation to Ex Parte Yarbrough, in which section 2 was applied to private interference. See notes 31-37 supra and accompanying text.

It must be noted that the criminal provisions of the Voting Rights Act do not on their face exclude interference with the right to vote on grounds other than race or color. See note 2 supra, and see H.R. REP. No. 439, 89th Cong., 1st Sess. 30 (1965). Under the strict approach to statutory construction of Reese and Cruikshank, the provisions would therefore be invalid. See notes 30 and 32 sitpra. However, it is to be doubted that the Court will follow the nineteenth century approach in refusing to supply this construction "by implication," especially in view of the terms of the preface to the Act, which defines its purpose specifically by reference to the fifteenth amendment.

One qualification ought to be added to emphasis in this Note on the practical need for extending congressional power under the fifteenth amendment to private conduct. Under the accepted interpretation of $E x$ Parte Yarbrough, Congress is already clearly empowered to prevent private interference with the right of all citizens to vote in federal elcetions. Except where state elections are held at separate times from federal elections, this doctrine will be sufficient to sustain federal proscription of all private voting intimidation under either the criminal provisions of the Voting Rights Act, 42 U.S.C. $\$ 1971(\mathrm{c}), 18$ U.S.C. $\$ 241$, or under the private civil remedy of 42 U.S.C. $\$ 1985$ (3). See Note, 74 YALE L.J. 1462 (1965). Adoption of Mr. Justice Black's theory that the fifteenth amendment confers a constitutional right will add that right to those now held to be within the provisions of 18 U.S.C. $\$ 241$ and 42 U.S.C. § 1985(3). Collins v. Hardyman, 341 U.S. 651 (1951); United States v. Williams, 341 U.S. 70 (1951).

80. See Mathews, Legislative and Judicial History of the Fifteentit AmendMent at 126, and Woodwarn, The BuRden of Southern History 84 (1960).

81. This Note takes no position as to whether the policy considerations which originally induced the Court to limit the fourteenth amendment to state action ought now to require the retention of the state action doctrine under that amendment. See note 21 supra. The Note simply maintains that, regardless of the utility of the state action requirement under the fourteenth amendment, it ought to be discarded as a limitation on the fifteenth amendment.

Analysis of the relevance or the weight of concern for the protection of local autonomy in setting the boundaries of fourteenth amendment power would require a discussion too 
the democratic values which favor local responsibility support rather than inhibit federal action to ensure the integrity of the local political process.

extensive to be undertaken here. Some observations may be in order, however. The objection of the nineteenth century Court to a liberal construction of the amendment can certainly not be disregarded, especially in view of the numerous "rights" since included in the due process clause. On the other hand, it is no longer possible to assure full protection to the southern Negro by confining federal jurisdiction over private racial offenses to the fifteenth amendment. Reprisals for attending integrated schools or for demanding equal treatment by federally financed state facilities under Title VI of the Civil Rights Act of 1964, for example, would escape federal preventive power under such an approach.

The state action problem under the fourteenth amendment is further complieated by the fact that the "breakdown" theory, which the nineteenth century Court invoked (note 8 supra), could not be administered by the courts without creating unmanageable confusion. This theory has proved appealing to some as a reconciliation of the perceived requirements of federalism with the needs for federal protection of the southern Negro. See, e.g., Harris, The Quest for Egualrty 53 (1960); Frantz, Congressional Pouler to Enforce the Fourteenth Amendment Against Private Acts, 73 YALE L.J. 1353, 1358-60 (1964). The only manner in which the theory could be put into practical operation would be via a congressional finding that Negroes in some areas were being denied equal protection of the laws by state and local officials to a degree that required federal protection of their fourteenth amendment rights. 